\title{
Post-mortem shrinkage of homograft aortic valves
}

\author{
F. DEXTER, R. J. DONNELLY, P. B. DEVERALL, \\ and D.A. WA TSON \\ Leeds Regional Tissue Bank, Pinderfields Hospital, Wakefield and Leeds Regional \\ Cardio-thoracic Surgical Centre, Killingbeck Hospital, Leeds
}

\begin{abstract}
Experience has shown that some frame-mounted homograft aortic valves, although competent immediately after mounting, are incompetent when subsequently presented for surgical use. Retraction and shrinkage of the cusps appears to be the cause of this change. Clinical and experimental studies have shown that shrinkage of homograft aortic valves occurs over an approximately five-day period after death of the donor and it is recommended that this period should elapse before mounting homograft aortic valves on to support frames.
\end{abstract}

We have previously described a technique for mounting and testing homograft aortic valves on rigid support frames. A clinical trial of such valves is at present in progress. Early in this trial it was noted that some valves were incompetent when tested immediately before use even though testing at the conclusion of the mounting procedure had revealed competence with correct cusp apposition. An analysis of the valves suggested that shrinkage had occurred in those valves mounted on frames within a few days of the death of the donor and not in those in which a delay had occurred. This hypothesis has been tested experimentally.

\section{MATERIALS AND METHODS}

A simple visual method of measuring the degree of cusp apposition was introduced so that any change could be accurately described (Fig. 1). Assessment was performed while the mounted valve was subjected to

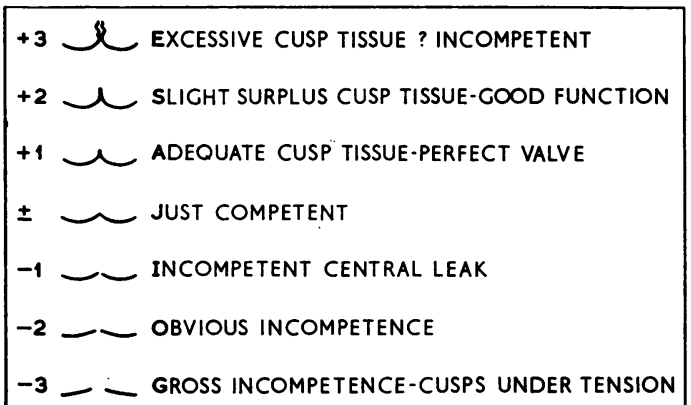

FIG. 1. Visual measurement of amount of cusp tissue apposition during examination of mounted homograft aortic valves under pressure in the testing apparatus. pressure in the testing apparatus previously described (Donnelly, Dexter, Deverall, and Watson, 1971.) Plus $\overrightarrow{0}$ $(+)$ signs indicate the degree of cusp apposition while $N$ minus ( - ) signs indicate the degree of cusp separation. The degree of cusp apposition is partly determined by the inherent structure of the individual valve. It can $\sum$ also be deliberately determined by the size of frame $\bar{\partial}$ into which the valve is mounted, for example, a plus 3 can be prepared by mounting a valve into a smaller $\frac{}{\Phi}$ sized frame and vice versa. The degree of cusp $\varrho$ apposition was recorded immediately after mounting, $\overrightarrow{\vec{O}}$ 48 hours after mounting, and subsequently when $\exists$ presented for surgical use.

Three groups of valves were studied.

GROUP I This group comprised six prepared valves presented for surgical use.

GROUP II This group comprised 20 valves deliberately mounted with varying degrees of cusp apposition. Ten valves were mounted at various times within five days 의 of the death of the donor while 10 were mounted after a five-day period had elapsed. Each of these two 윽 groups of 10 valves was further subdivided in that $D$ different methods of preservation were used. Three were maintained without antibiotics at $4^{\circ} \mathrm{C}$; three were maintained with antibiotics at $4^{\circ} \mathrm{C}$ for seven days after $\circ$ which the temperature was raised to $37^{\circ} \mathrm{C}$ for a N further 21 days; and four valves were maintained at $N$ $37^{\circ} \mathrm{C}$ from the outset. All valves were preserved in $\omega$ isotonic saline. Antibiotics, if used, were penicillin, 100 units $/ \mathrm{ml}$, and streptomycin, $0.1 \mathrm{mg} / \mathrm{ml}$.

GROUP III This group comprised 13 valves prepared $\stackrel{\mathcal{D}}{+}$ for surgical use. All valves in this group were mounted $\square$ according to our described technique and after the $\bar{O}$ five-day period had elapsed. Sterilization of these $\mathbb{D}$ valves was obtained with gamma radiation-2.5 Megarads from a spent fuel source. The valves were $\varrho$ maintained at $4^{\circ} \mathrm{C}$ before, during, and after irradiation. 
T A B L E I

GROUP I

\begin{tabular}{|c|c|c|c|c|c|c|}
\hline \multirow[b]{2}{*}{ Valve No. } & \multirow{2}{*}{$\begin{array}{l}\text { Mounted after } \\
\text { Death of Donor } \\
\text { (days) }\end{array}$} & \multicolumn{2}{|c|}{ Cusp Apposition } & \multirow{2}{*}{$\begin{array}{c}\text { Valve presented } \\
\text { for Surgery } \\
\text { (days after mounting) }\end{array}$} & \multirow{2}{*}{$\begin{array}{l}\text { Cusp Apposition } \\
\text { when Presented } \\
\text { for Surgery }\end{array}$} & \multirow{2}{*}{$\begin{array}{c}\text { Change in Degree } \\
\text { of Cusp } \\
\text { Apposition }\end{array}$} \\
\hline & & $\begin{array}{c}\text { After } \\
\text { Mounting }\end{array}$ & $\begin{array}{l}48 \mathrm{hr} \text { after } \\
\text { Mounting }\end{array}$ & & & \\
\hline $\begin{array}{l}\mathrm{KB} / \mathbf{A} / 55 \\
\mathrm{~KB} / \mathbf{A} / 54 \\
\mathrm{~KB} / \mathbf{A} / 59 \\
\mathrm{~KB} / \mathbf{A} / 61 \\
\mathrm{~KB} / \mathbf{A} / 66 \\
\mathrm{~KB} / \mathbf{A} / 65\end{array}$ & $\begin{array}{l}2 \\
5 \\
6 \\
4 \\
3 \\
3\end{array}$ & $\begin{array}{l}+1 \\
+1 \\
+1 \\
+2 \\
+1 \\
+3\end{array}$ & $\begin{array}{l}\text { Not tested } \\
\text { Not tested } \\
\text { Not tested } \\
\text { Not tested } \\
\text { Not tested } \\
\text { Not tested }\end{array}$ & $\begin{array}{r}2 \\
8 \\
48 \\
34 \\
13 \\
5\end{array}$ & $\begin{array}{l}-2 \\
+1 \\
+1 \\
+1 \\
-1 \\
+1\end{array}$ & $\begin{array}{l}-3 \\
\mathrm{Nil} \\
\mathrm{Nil} \\
-1 \\
-2 \\
-2\end{array}$ \\
\hline
\end{tabular}

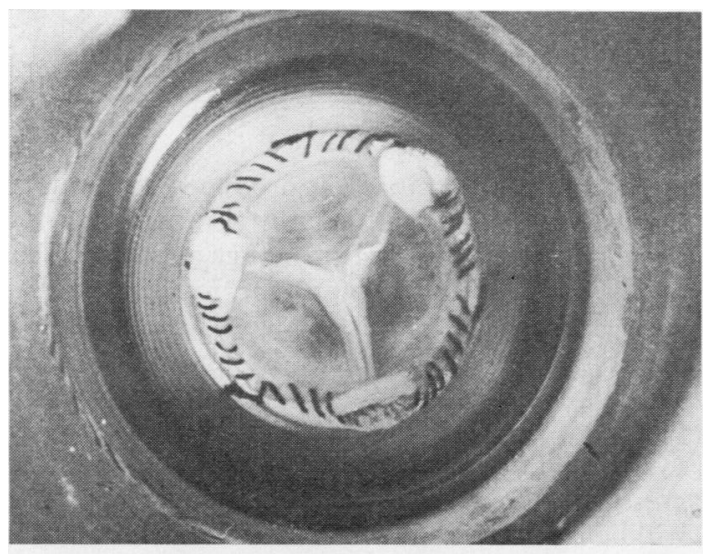

(a)

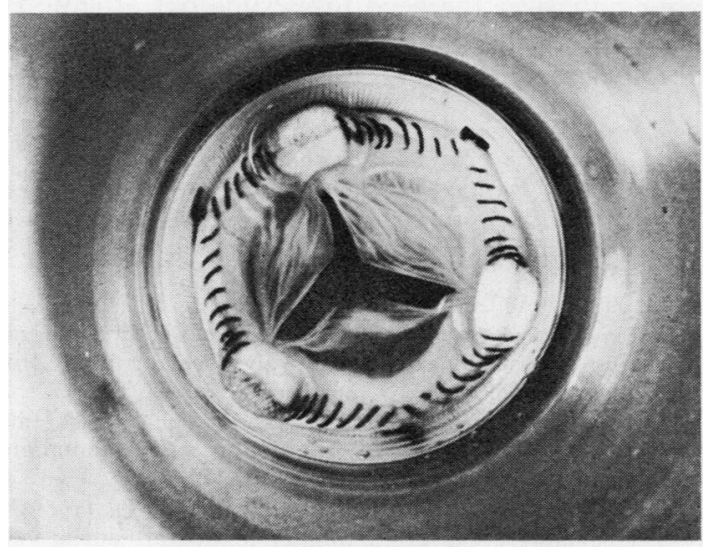

(b)

FIG. 2 (a). Frame-mounted homograft aortic valve in the testing chamber. This valve was mounted on its support frame with +3 surplus cusp tissue immediately after dissection of the valve from the heart 48 hours after the death of the donor. (b) The same valve examined 48 hours later under identical conditions. Considerable retraction and shrinkage of the cusp leaflets has occurred.

\section{RESULTS}

GROUP I Two out of the six valves, competent immediately after mounting, were incompetent with marked cusp retraction when tested before surgical use. Two others had less cusp apposition than originally recorded. Two valves appeared unchanged. Analysis of our records showed that there was a relation between cusp retraction and early frame mounting. Valves mounted immediately after dissection showed more shrinkage than valves mounted 24 hours after dissection while the two valves mounted 72 hours or more after dissection showed no shrinkage. Since, in general, between 24 and 48 hours elapses between the death of the donor and valve dissection, we feel that the shrinkage period covers about a five-day period (Table I).

GROUP II Findings similar to those just described were found in this group. Valves mounted early after dissection all had, in varying degrees, cusp retraction while this was minimal or absent in those valves mounted later. In the small number of valves in the subgroups in which differing storage temperature conditions were used no significant differences were noted. Clearly, homograft valve availability is limited and a much larger series is necessary before a categorical statement about preservation conditions can be made. However, no evidence exists at this time to contradict the basic hypothesis linking shrinkage to the time of mounting.

The maximum degree of observed shrinkage is illustrated in Figures $2 a$ and $b$. This valve was mounted immediately after dissection and was satisfactory when examined after mounting under pressure in the testing apparatus (Fig. 2a). Subsequent re-testing 48 hours later revealed central incompetence with uniform cusp retraction (Fig. 2b).

GROUP III The findings in this second clinical series are shown in Table II. All valves in this group were mounted at least three days after the 
T A B LE II

GROUP III

\begin{tabular}{|c|c|c|c|c|c|c|}
\hline \multirow{2}{*}{ Valve No. } & \multirow{2}{*}{$\begin{array}{l}\text { Mounted after } \\
\text { Death of Donor } \\
\text { (days) }\end{array}$} & \multicolumn{2}{|c|}{ Cusp Apposition } & \multirow{2}{*}{$\begin{array}{c}\text { Valve Presented } \\
\text { for Surgery } \\
\text { (days after mounting) }\end{array}$} & \multirow{2}{*}{$\begin{array}{l}\text { Cusp Apposition } \\
\text { when Presented } \\
\text { for Surgery }\end{array}$} & \multirow{2}{*}{$\begin{array}{l}\text { Change in Degree } \\
\text { of Cusp } \\
\text { Apposition }\end{array}$} \\
\hline & & $\begin{array}{c}\text { After } \\
\text { Mounting }\end{array}$ & $\begin{array}{l}48 \mathrm{hr} \text { after } \\
\text { Mounting }\end{array}$ & & & \\
\hline 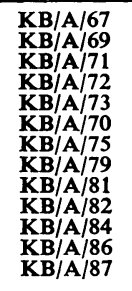 & $\begin{array}{l}4 \\
3 \\
5 \\
5 \\
5 \\
4 \\
4 \\
5 \\
7 \\
6 \\
7 \\
4 \\
6\end{array}$ & $\begin{array}{l}+2 \\
+3 \\
+1 \\
+1 \\
+1 \\
+2 \\
+2 \\
+1 \\
+2 \\
+2 \\
+2 \\
+2 \\
+1\end{array}$ & $\begin{array}{l}+1 \\
+1 \\
+1 \\
+1 \\
+1 \\
+1 \\
+1 \\
+1 \\
+2 \\
+2 \\
+2 \\
+1 \\
+1\end{array}$ & $\begin{array}{r}19 \\
19 \\
8 \\
18 \\
42 \\
142 \\
12 \\
42 \\
45 \\
35 \\
21 \\
7 \\
8\end{array}$ & $\begin{array}{l}+1 \\
+1 \\
+1 \\
+1 \\
+1 \\
+1 \\
+1 \\
+1 \\
+2 \\
+2 \\
+2 \\
+1 \\
+1\end{array}$ & $\begin{array}{l}-1 \\
-2 \\
\text { Nil } \\
\text { Nil } \\
\text { Nil } \\
-1 \\
-1 \\
\text { Nil } \\
\text { Nil } \\
\text { Nil } \\
\text { Nil } \\
-1 \\
\text { Nil }\end{array}$ \\
\hline
\end{tabular}

death of the donor. Some of the valves have now been used for valve replacement, in which case they were examined in the testing apparatus before surgical use. All of the valves were re-tested 48 hours after being mounted. Five valves underwent some degree of cusp shrinkage and in each case mounting had taken place before the fifth day after the death of the donor. No valve mounted after five days underwent demonstrable shrinkage.

\section{DISCUSSION}

The early clinical experience with frame-mounted homograft aortic valves was disappointing (Watson et al., 1968; Donnelly, Rhea, and Watson 1969). We have previously described the development of a technique for mounting and testing such valves so that mechanical integrity could be ensured at the time of surgical use (Donnelly et al., 1971). It is realized that precise cusp apposition is of major importance in determining valve function. Careful observation of cusp apposition led to our noting minor changes in some valves. These changes had resulted in functional impairment and were demonstrated in the testing apparatus when presented for surgical use. Harris, Kovalik, Marks and Malm (1968) and Trimble, Suri, and Silver (1969) have studied the effects of differing methods of valve preparation on the degree of cusp apposition but we are not aware of any studies concerning valve shrinkage after donor death and subsequent dissection. It is probable that all the components of the homograft aortic valve are subject to shrinkage. Changes in cusp apposition would not occur, however, unless the aortic wall, and hence the commissural attachments, were prevented from shrink- ing and this is the situation produced by mounting the valve on a rigid support frame. Our data appear to show that the shrinkage process, at leas under our conditions of donor refrigeration and valve storage, is a time-related phenomenon, the major change occurring within a five-day period. The data presented in Table II support this con tention.

A limited clinical trial of these valves is in pro gress and the early results are encouraging. Thes will be reported in due course. It is clear that valves with shrinkage have not been used clinically sinceit the introduction of our technique of pressure testing immediately before surgical use. This study re-emphasizes the need for scrupulous attention tọ detail in the preparation and use of frame-mounted biological valves.

\section{REFERENCES}

Donnelly, R. J., Dexter, F., Deverall, P. B., and Watson D. A. (1971). A new technique for mounting and testing frame-supported homograft aortic valves. Thorax, 2హ, 174.

—, Rhea, W. G., and Watson, D. A. (1969). Further experience with the Killingbeck-Lusterlite graft suppon ring for aortic and mitral valve replacement. Ame Surgn, 35, 895.

Harris, P. D., Kovalik, A. T. W., Marks, J. A., and Malm? J. R. (1968). Factors modifying aortic homografo structure and function. Surgery, 63,45 .

Trimble, A. S., Suri, R. K., and Silver, M. D. (1969). cinematographic evaluation of homograft aortic vali function using an internal pulse duplicator. Part II. The effects of sterilization and storage. J. thorac. cardiovas Surg., 58, 54.

Watson, D. A., Pearson, K. W., Cawley, J. C., Rhea, W. G Donnelly, R. J., and Dexter, F. (1968). Aortic valve replacement with Dacron-supported grafts. Thorax, $2 \frac{8}{8}$ 621. 